\title{
RAPID REPRODUCTIVE ANALYSIS AND LENGTH-WEIGHT RELATIONS OF THREE REEF FISHES (ACTINOPTERYGII: PERCIFORMES AND TETRAODONTIFORMES) FROM A REMOTE SITE IN PAPUA NEW GUINEA
}

\author{
Ken LONGENECKER ${ }^{1 *}$, Ross LANGSTON ${ }^{1,2}$, Utula KONDIO ${ }^{3}$, Holly BOLICK ${ }^{1}$, \\ and Mara MULROONEY ${ }^{4}$ \\ ${ }^{1}$ Department of Natural Sciences, Bishop Museum, Honolulu, Hawaii, USA \\ ${ }^{2}$ Department of Natural Sciences, Windward Community College, Kaneohe, Hawaii, USA \\ ${ }^{3}$ Kamiali Wildlife Management Area, Lababia, Morobe Province, Papua New Guinea \\ ${ }^{4}$ Department of Anthropology, Bishop Museum, Honolulu, Hawaii, USA
}

\begin{abstract}
Longenecker K., Langston R., Kondio U., Bolick H., Mulrooney M. 2016. Rapid reproductive analysis and length-weight relations of three reef fishes (Actinopterygii: Perciformes and Tetraodontiformes) from a remote site in Papua New Guinea. Acta Ichthyol. Piscat. 46 (3): 263-270.
\end{abstract}

\begin{abstract}
We present length-weight relations (LWR) and use rapid, low-cost histological methods to describe the reproductive biology of three reef fishes from a remote area in Papua New Guinea: the striped monocle bream, Scolopsis lineata Quoy et Gaimard, 1824; the Indian goatfish, Parupeneus indicus (Shaw, 1803); and the blackbelly triggerfish, Rhinecanthus verrucosus (Linnaeus, 1758). The LWR for Scolopsis lineata is $W=$ $0.0191 \mathrm{FL}^{3.02}$. Male $L_{50}$ is 11.2 and female $L_{50}$ is $13.5 \mathrm{~cm} \mathrm{FL}$. Overall sex ratio is female biased; however, for mature individuals, females dominate size-classes from 13 through $15 \mathrm{~cm}$ and males dominate smaller and larger size classes. This species is a batch-spawning, protogynous hermaphrodite. The LWR for Parupeneus indicus is $W=0.00904 \mathrm{FL}^{3.25}$. Male $L_{m}$ is 14.7 and female $L_{50}$ is $18.4 \mathrm{~cm} \mathrm{FL}$. Overall sex ratio is $1: 1$; however, for mature individuals, females dominate size-classes from 17 through $22 \mathrm{~cm}$ and males dominate smaller and larger size classes. This species is a batch-spawning gonochore. $\mathrm{BF}=4.62 \mathrm{FL}^{2.95}$. The LWR for Rhinecanthus verrucosus is $W=0.0257 \mathrm{TL}^{2.97}$. Male $L_{50}$ is 13.0 and female $L_{50}$ is $14.1 \mathrm{~cm}$ TL. Overall sex ratio is female biased; however, mature individuals are male biased $\geq 16.1 \mathrm{~cm}$ TL and, effectively, exclusively male $\geq 17.6 \mathrm{~cm}$. This species is a batch-spawning gonochore. $\mathrm{BF}=3.35 \cdot 10^{-19} \mathrm{TL}^{19.4}$.
\end{abstract}

Keywords: size-at-maturity, reproductive mode, size-specific sex ratios, batch fecundity, Morobe Province

To address the large knowledge gap in reproductive information for exploited fishes (Froese and Binohlan 2000), we initiated a research program focused on the reproduction of Pacific coral-reef fishes. We used recently developed methods for rapid, low-cost, on-site, histologybased reproductive analysis that requires minimal research infrastructure (Longenecker et al. 2013a, 2013b, 2014). These methods use standard techniques (e.g., plastic embedding) that have been modified such that work can be conducted in remote field settings without electrical service. With these methods, reproductive information can be generated quickly and at low cost, thus eliminating the perceived impediments to broad-scale reproductive analysis of coral-reef fishes (Roberts and Polunin 1993, Johannes 1998). However, in the interest of rapidly increasing the amount of available reproductive information, we analyze only one gonad subsample from the minimum number of specimens necessary to generate estimates of reproductive parameters. Therefore, results of our rapid reproductive analysis should be viewed as preliminary.

Our research program consists of annual, two-week field trips to the subsistence-fishing village of Lababia, Papua New Guinea (PNG), which holds traditional tenure over the waters of the Kamiali Wildlife Management Area (KWMA hereafter) (Fig. 1). Each year, village residents use the following criteria to choose four study species:

- All are an important part of village fish catch;

- Residents are interested in learning more about each species;

- Published reproductive information is lacking or incomplete;

- Each species is distinctive enough that the chance of misidentification is low.

* Correspondence: Dr. Ken Longenecker, Department of Natural Science, Bishop Museum, 1525 Bernice Street, Honolulu, HI, 96817, USA, phone: +1 808 847 8273, fax +1 808847 8252, e-mail: (KL) klongenecker@bishopmuseum.org, (RL) langston@hawaii.edu, (HB) holly@bishopmuseum.org, (MM) mara@bishopmuseum.org. 


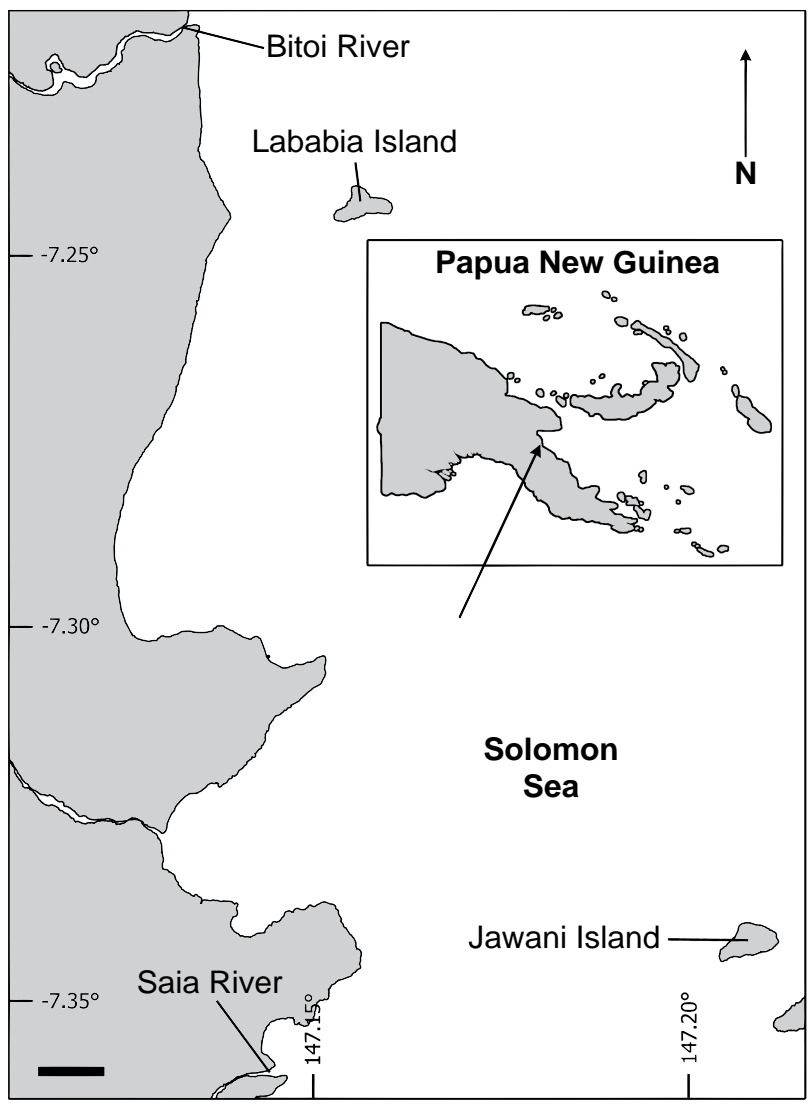

Fig. 1. Map of the sampling area; Kamiali Wildlife Management Area, Papua New Guinea, is bounded by the Bitoi and Saia Rivers and includes Lababia and Jawani Islands; Scale bar $=1 \mathrm{~km}$

Village residents, through regular fishing activities from 17 February-17 March 2014, caught an adequate number of specimens for the reproductive analysis of three species. These were the striped monocle bream, Scolopsis lineata Quoy et Gaimard, 1824; the Indian goatfish, Parupeneus indicus (Shaw, 1803); and the blackbelly triggerfish, Rhinecanthus verrucosus (Linnaeus, 1758). All three species occur in the Indo-West Pacific. The range of Scolopsis lineata stretches from the Cocos (Keeling) Islands to the Marshall Islands and Vanuatu, and from the Ryukyu Islands to northwestern Australia (Russell 1990). The range of Parupeneus indicus extends from the east coast of Africa to Samoa; in the Indian Ocean from the southern Arabian Peninsula to South Africa and in the western Pacific from southern Japan to the southern Great Barrier Reef (Randall 2001). The range of Rhinecanthus verrucosus spreads from the Chagos Archipelago to the Solomon Islands, and from southern Japan to Vanuatu (Matsuura 2001). Outside of KWMA, $P$. indicus is a highly esteemed food fish (Randall 2001), whereas S. lineata appears occasionally in small numbers in local markets, although there is no major fishery for the species (Russell 1990), and R. verrucosus is described as of minor importance to fisheries (Matsuura 2001).

Specimens were caught by hook-and-line, spear, and Derris fishing (based on rotenone poisoning). Fish lengths, weights, and gonad samples were obtained within a few hours of being caught. All collections were made with the approval of relevant local and national authorities. We followed the guidance of Froese et al. (2011) to determine length-weight relations for fresh-caught specimens and, with the following modifications, used methods described in Longenecker et al. (2013b) to describe size-at-maturity, reproductive mode, sex-ratios, and length-batch fecundity relations. For batch fecundity analysis, we liberated oocytes from the stroma by vigorous shaking rather than using an ultrasonic cleaner. Length-batch fecundity relations were determined using linear regression analysis of log-transformed data rather than curvilinear regression analysis of raw data. Results are summarized in Table 1 and presented more fully in separate sections for each species, below.

Scolopsis lineata. Total body weight $(W)$ in $g$ is an approximately cubic function of fork length (FL) in $\mathrm{cm}$ (Table 1, Fig. 2A). The 95\% CI of regression parameters $a$ and $b$ are $0.0104-0.0351$ and $2.80-3.25$, respectively $\left(r^{2}\right.$ $=0.870, n=105$, FL range: $12.2-16.4, W$ range: $40-90)$. ANCOVA did not detect a significant sex-based difference in the length-weight relation for this population $(F=2.26$, $\mathrm{DF}=1, P=0.137$ ).

We histologically examined gonads of two (2) undifferentiated, 42 male, and 72 female Scolopsis lineata. Ovaries of mature females contained several discrete stages of oocytes, indicating group-synchronous oocyte development (Wallace and Selman 1981). We therefore classify $S$. lineata as a batch spawner. We grouped males into $2-\mathrm{cm}$ and females into $1-\mathrm{cm}$ size classes to estimate size at maturity. Sexual differentiation occurred around 10 $\mathrm{cm}$ FL. Ovaries contained vitellogenic oocytes in females as small as $11.8 \mathrm{~cm}$ FL. Immature females (range 10.715.8) were scattered throughout the size range of mature females (range 13.2-15.9). We estimate female $L_{50}$ at $13.5 \mathrm{~cm}$ FL (Fig. 2B). The smallest male with spermiated testes was $11.8 \mathrm{~cm}$ FL. For males, the size at which 50\% of individuals are mature $\left(L_{50}\right)$ was $11.2 \mathrm{~cm}$ FL (Fig. 2B). This estimate assumes one-half of undifferentiated specimens were male. All males $>14.1 \mathrm{~cm}$ were mature.

We saw several suggestions of sex change in Scolopsis lineata. The mean length of all male S. lineata was significantly larger than that of all females $(t=-2.63, \mathrm{DF}=$ $69, P=0.010$ ). Additionally, the mean length of functional males was significantly larger than that of functional females $(t=-3.09, \mathrm{DF}=56, P=0.003)$. A total of 21 fish ( $18.1 \%$ of all histologically examined specimens) had presumptive ovotestes (Fig. 2C). Twenty of these were dominated by primary-growth $(n=10)$ or vitellogenic $(n$ $=10$ ) oocytes and had clusters of inactive spermatocysts within the gonad wall or along the periphery of the gonad. Conversely, the gonad of one functional male contained remnants of primary growth oocytes in its periphery. Sex change is common among nemipterids; when present, transition may be pre- or post-maturational (Russell 1990). In species with pre-maturational sex change, juvenile (i.e., inactive) gonads contain readily identifiable ovarian and testicular tissue. In contrast, the majority of the inactive S. lineata gonads were entirely ovarian (20) or testicular (4) 
Table 1

Summary of length-weight relations and reproductive information for striped monocle bream, Scolopsis lineata, Indian goatfish, Parupeneus indicus, and blackbelly triggerfish, Rhinecanthus verrucosus, from the Kamiali Wildlife Management Area, Papua New Guinea

\begin{tabular}{|c|c|c|c|}
\hline \multirow{2}{*}{ Parameter } & \multicolumn{3}{|c|}{ Fish species } \\
\hline & Scolopsis lineata & Parupeneus indicus & Rhinecanthus verrucosus \\
\hline Length-Weight Relation & $W=0.0191(\mathrm{FL})^{3.02}$ & $W=0.00904(\mathrm{FL})^{3.25}$ & $W=0.0257(\mathrm{TL})^{2.97}$ \\
\hline${ }^{\lambda} L_{\mathrm{m}}$ & 11.8 & 14.7 & 13.8 \\
\hline$q L_{\mathrm{m}}$ & 13.2 & 13.7 & 12.9 \\
\hline$\widehat{o} L_{50}$ & 11.2 & - & 13.0 \\
\hline$q L_{50}$ & 13.5 & 18.4 & 14.1 \\
\hline Reproductive mode & Protogyny & Gonochore & Gonochore \\
\hline Oocyte development & Group synchronous & Group synchronous & Group synchronous \\
\hline Sex ratio (overall) $\delta: q$ & $1: 1.71$ & $1: 1.11$ & $1: 3.10$ \\
\hline Sex ratio (mature) $\delta: q$ & $1: 1.14$ & $1: 0.83$ & $1: 1.78$ \\
\hline Size-specific sex ratio & $\%$ \% $=93.4 e^{\left(-0.5\left(\frac{\mathrm{FL}-13.9}{0.66}\right)^{2}\right.}$ & $\%$ \% $=55.4 e^{\left(-0.5\left(\frac{\mathrm{FL}-19.6}{4.79}\right)^{2}\right)}$ & $\% \propto=\frac{94.1}{1+e^{-\left(\frac{\mathrm{TL}-16.1}{-0.28}\right)}}$ \\
\hline Batch fecundity & - & $\mathrm{BF}=4.62(\mathrm{FL})^{2.95}$ & $\mathrm{BF}=3.35 \cdot 10^{-19}(\mathrm{TL})^{19.4}$ \\
\hline
\end{tabular}

$L_{m}=$ minimum mature length (the smallest mature individual observed during the presently reported study), $L_{50}=$ length at $50 \%$ maturity ( $50 \%$ of all individuals at this length are expected to be mature).

whereas only 10 were ovotestes. Also, analysis of variance detected a significant difference amongst the mean lengths of females, transitional individuals, and males $(F=14.46$, $\mathrm{DF}=112, P<0.001)$. Tukey's Pairwise Comparison indicates that transitional individuals were significantly longer than females, but did not differ from males. This suggests that the majority of females initially develop an entirely ovarian gonad, which subsequently matures and functions exclusively as female, but that some larger females transform into males. Given our results and that protogyny has been reported in four Scolopsis species (Young and Martin 1985, Akita and Tachihara 2014), we tentatively classify $S$. lineata as a protogynous hermaphrodite.

Overall sex ratio in this Scolopsis lineata population is female-biased (Table $1, \chi^{2}=7.89, \mathrm{DF}=1, P=0.005$ ). Considering only mature individuals, the observed sex ratio was not significantly different from $1: 1\left(\chi^{2}=0.325\right.$, $\mathrm{DF}=1, P=0.569)$. However, we did see size-specific sex ratios in the mature size classes; the sex ratio of mature individuals varied predictably with length. Smaller size classes are male biased, switch to a female-biased state as length increases, and the largest size classes are male biased (Fig. 2D). An equation describing the percent of mature females $(\%$ O $)$, throughout the size range of mature specimens (Table $1, r^{2}=0.854$ ), predicts that the population is female biased between 13.1 and $14.6 \mathrm{~cm} \mathrm{FL}$, but male biased at smaller and larger sizes, and nearly exclusively male near minimum and maximum lengths of mature specimens. Similar patterns, with larger size classes being male-dominated, have been reported in many nemipterids (Young and Martin 1985, Russell 1990, Lau and Sadovy 2001, Mant et al. 2006, Boaden and Kingsford 2013).

We frequently misclassified the status of ovaries during macroscopic examination (incorrectly judging that there were no late-vitellogenesis oocytes). This error left us with too few $(n=3)$ subsamples for batch fecundity analysis.

Parupeneus indicus. Overall, total body weight $(W)$ in $\mathrm{g}$ is an approximately cubic function of FL in $\mathrm{cm}$ (Table 1, Fig. 3A). The $95 \% \mathrm{CI}$ of regression parameters $a$ and $b$ are $0.00724-0.0113$ and $3.17-3.32$, respectively $\left(r^{2}=\right.$ $0.982, n=120$, FL range: $13.0-29.3, W$ range: $40-490)$. ANCOVA did not detect a significant sex-based difference in the length-weight relation for this population $(F=0.60$, $\mathrm{DF}=1, P=0.442$ ).

We histologically examined gonads of one (1) undifferentiated, 47 male, and 52 female Parupeneus indicus. Ovaries of mature females contained several discrete stages of oocytes, indicating group-synchronous oocyte development (Wallace and Selman 1981). We therefore classify $P$. indicus as a batch spawner. Sexual differentiation occurred around $12 \mathrm{~cm} \mathrm{FL}$. Ovaries contained vitellogenic oocytes in females as small as 13.7 cm FL. We estimate female $L_{50}$ at $18.4 \mathrm{~cm} \mathrm{FL} \mathrm{(Fig.} \mathrm{3B).}$ The smallest male with spermiated testes was $14.7 \mathrm{~cm}$ FL. All males from 24.0 to $29.3 \mathrm{~cm}$ FL were mature. Because all size classes contained more than $50 \%$ mature males, we could not reliably estimate male $L_{50}$.

We saw a sex-based bimodal size distribution in Parupeneus indicus. A $t$-test indicated mean length of males is significantly greater than that of females $(t=$ $-2.87, \mathrm{DF}=97, P=0.005)$. There was no other evidence of sex change in $P$. indicus. We did not see a central membrane-lined lumen in testes, nor did any gonad contain a mixture of ovarian and spermatogenic tissue. In agreement with studies of congeners (Longenecker and Langston 2008, Longenecker et al. 2011), we classify $P$. indicus as a gonochore. 
Overall sex ratio in this Parupeneus indicus population is not significantly different from $1: 1$ (Table $1, \chi^{2}=0.253$, $\mathrm{DF}=1, P=0.615)$, nor does the sex ratio of mature individuals differ from $1: 1\left(\chi^{2}=0.545, \mathrm{DF}=1, P=0.460\right)$. However, we did see size-specific sex ratios in the mature size classes; the sex ratio of mature individuals varied predictably with length. Smaller size classes were male biased, switch to a female-biased state as length increased, and the largest size classes were male biased (Fig. 3C). An equation describing the percent of mature females $(\%+)$, throughout the size range of mature specimens (Table $1, r^{2}=0.94$ ), predicts that the population was female biased between 17.4 and $21.7 \mathrm{~cm}$ FL, but male biased at smaller and larger sizes, and approximately $95 \%$ male near the maximum length of mature specimens. Similar patterns, with larger size classes being male-dominated, have been reported for congeners (Anand and Pillai 2002, Longenecker et al. 2011, Pavlov et al. 2011, Leba unpublished*).

Batch fecundity (BF) is an approximately cubic function of length for Parupeneus indicus (Table 1, Fig. $3 \mathrm{D})$. However, the regression model is poorly descriptive $\left(r^{2}=0.220\right)$.

Rhinecanthus verrucosus. Overall, total body weight $(W)$ in $\mathrm{g}$ is an approximately cubic function of TL in $\mathrm{cm}$
(Table 1, Fig. 4A). The $95 \%$ CI of regression parameters $a$ and $b$ are $0.0186-0.0356$ and $2.85-3.09$, respectively $\left(r^{2}=0.957, n=112\right.$, TL range: $11.4-19.5, W$ range: $\left.40-180\right)$. ANCOVA did not detect a significant sex-based difference in the length-weight relation for this population $(F=0.07$, $\mathrm{DF}=1, P=0.793$ ).

We histologically examined gonads of 90 female, and 29 male Rhinecanthus verrucosus. Ovaries of mature females contained several discrete stages of oocytes, indicating group-synchronous oocyte development (Wallace and Selman 1981). We therefore classify $R$. verrucosus as a batch spawner. Ovaries contained vitellogenic oocytes in females as small as $12.9 \mathrm{~cm} \mathrm{TL}$, however inactive females occurred in all size classes we examined. We estimate female $L_{50}$ at $14.1 \mathrm{~cm}$ TL (Fig. 4B). This estimate ignores the largest size class, represented by a single inactive female. The smallest male with spermiated testes was $13.8 \mathrm{~cm}$ TL. All but three larger specimens (within the 18 $\mathrm{cm}$ size class) were mature. For males, the size at which $50 \%$ of individuals are mature $\left(L_{50}\right)$ is $13.0 \mathrm{~cm}$ TL (Fig. 4B). All males $\geq 19.4 \mathrm{~cm}$ were mature $(n=2)$.

We saw a sex-based bimodal size distribution in Rhinecanthus verrucosus. A $t$-test indicated mean length of males is significantly greater than that of females $(t=$
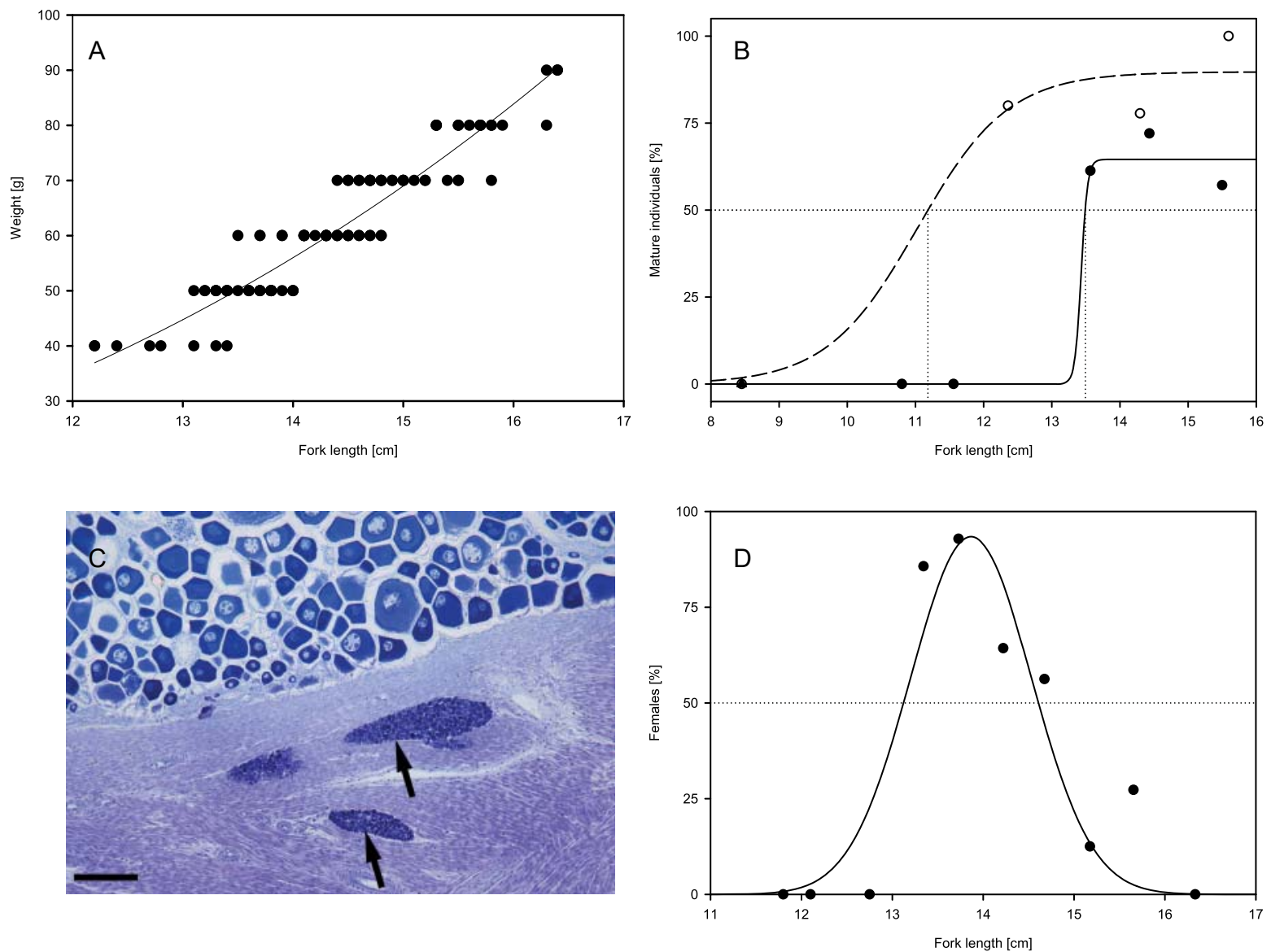

Fig. 2. Scolopsis lineata from the Kamiali Wildlife Management Area, Papua New Guinea: Length-weight relation (A); $L_{50}$ for males (open circles, dashed line) and females (closed circles, solid line), undifferentiated individuals are represented by triangles (B); An ovotestis from a $15.5 \mathrm{~cm}$ FL individual, arrows indicate clusters of inactive spermatocysts within the gonad wall, scale bar $=100 \mu \mathrm{m}(\mathbf{C})$; size-specific sex ratios for mature individuals (D)

* Leba H. 2009. Reproductive biology of three Hawaiian goatfishes, Mulloidichthys vanicolensis, M. flavolineatus and Parupeneus porphyreus (Perciformes: Mullidae). 
$-4.68, \mathrm{DF}=32, P<0.0001)$. There was no other evidence of sex change in $R$. verrucosus. We did not see a central membrane-lined lumen in testes, nor did any gonad contain a mixture of ovarian and spermatogenic tissue. We classify $R$. verrucosus as a gonochore.

Overall sex ratio in this Rhinecanthus verrucosus population is female biased (Table $1, \chi^{2}=31.3, \mathrm{DF}=1$, $P<0.0001)$. Considering only mature individuals, the observed sex ratio is also female biased $\left(\chi^{2}=5.06, \mathrm{DF}=\right.$ $1, P=0.0244)$. However, we did see size-specific sex ratios in the mature size classes; the sex ratio of mature individuals varied predictably with length (Fig. 4C). An equation describing the percent of mature females $(\% q)$, throughout the size range of mature specimens (Table $1, r^{2}=0.99$ ), predicts that the population becomes male biased $\geq 16.1 \mathrm{~cm}$ TL. Moreover, the percentage of females was $<0.5 \%$, or effectively zero $\geq 17.6 \mathrm{~cm}$ TL.

Batch fecundity (BF) is an unusually high exponential function of fish length (over a very restricted range of $1.5 \mathrm{~cm}$ ) for Rhinecanthus verrucosus (Table 1, Fig. 4D, $\left.r^{2}=0.538\right)$. This may be related to the extremely small scaling factor; the two appear to be inversely related when fecundity is modeled as a power function of length (Ebisawa 2006).

We reiterate that the results of rapid reproductive analysis should be considered preliminary. For instance, to confirm our hypothesis that Scolopsis lineata is a protogynous hermaphrodite we would need to examine a greater number of specimens and section the entire gonad serially rather than just obtaining a few (usually 16-20) sections for each specimen, as was done for this study. However, we think our results are a useful contribution to the currently insufficient body of knowledge about reproduction in Pacific coral-reef fishes.

For instance, females of all species in this study become less abundant as size class increases, representing between five and, effectively, zero percent of individuals in the largest size class. The impact of these size-specific sex ratios on estimates of population-level egg production is currently under-recognized (but see Longenecker et al. 2014). It is a common assumption that large fish are disproportionately responsible for population-level reproductive output because large females produce many more eggs than small females (see Roberts and Polunin 1993, Allison et al. 1998, Halpern 2003, Froese 2004, Birkeland and Dayton 2005, Sale et al. 2005). However, the assumption may not hold if females are rare in the largest size classes and cannot hold if females are absent. The curves in Fig. 5A show the relation between length and expected individual batch fecundity with observed overall sex ratios and with observed size-specific sex ratios. Expected individual batch fecundity at a given
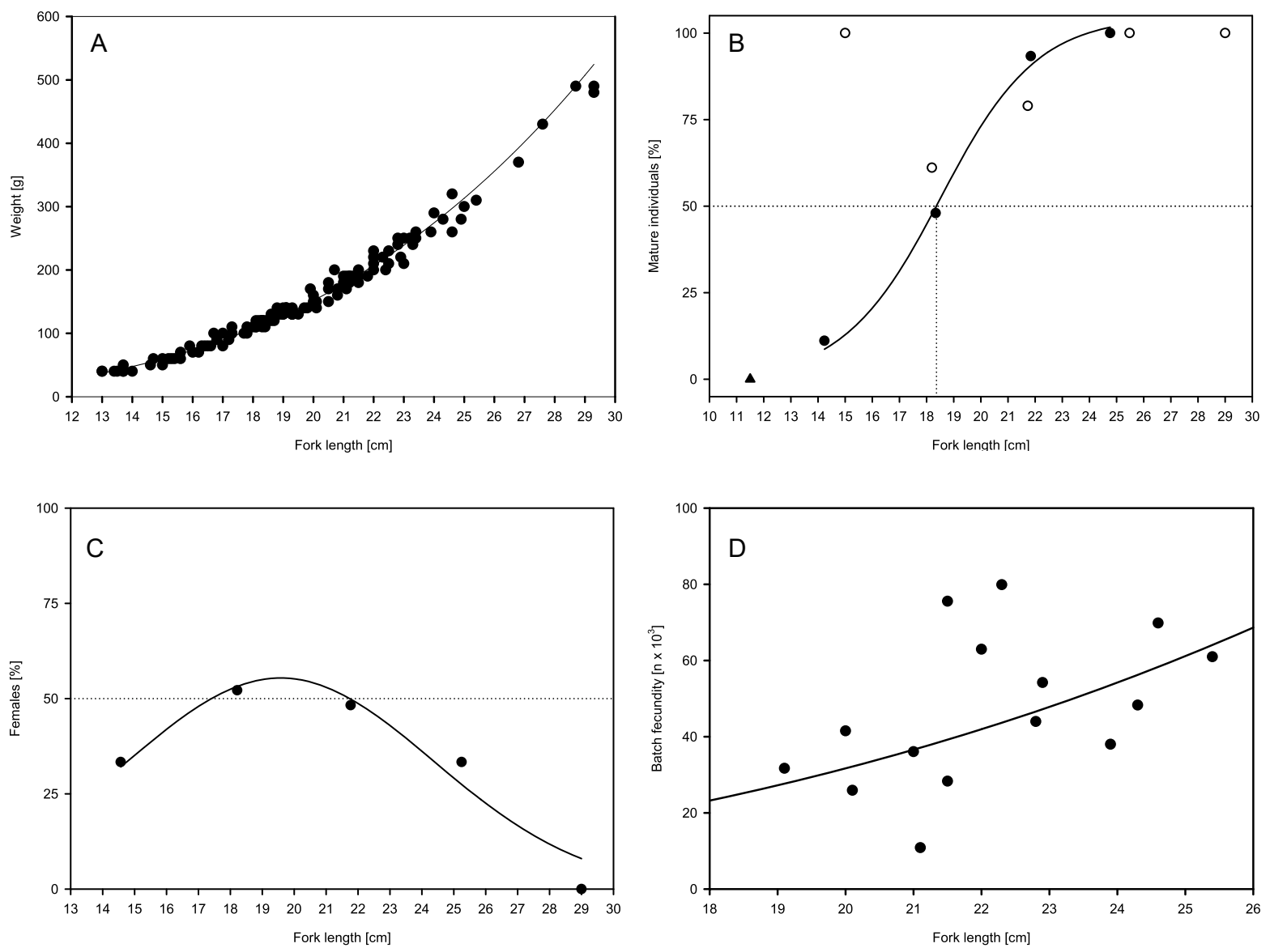

Fig. 3. Parupeneus indicus from the Kamiali Wildlife Management Area, Papua New Guinea: Length-weight relation (A); $L_{50}$ for females (closed circles, solid line), males and undifferentiated individuals are represented by open circles and triangles, respectively (B); Size-specific sex ratios for mature individuals (C); Length-fecundity relation (D) 
length is the product of the result of the length-fecundity relation and the proportion of females at that length. Thus the curves represent the expected batch fecundity of any individual in the population, not just females. For both examples, the small chance of an individual being a female eventually overwhelms increases in batch fecundity such that expected egg production per individual peaks well below maximum observed length (Fig. 5, solid curves). More importantly, failing to account for sizespecific sex ratios at the largest observed specimen size leads to a 1.4 million percent overestimate (3 013220 vs. 21 eggs) in expected individual batch fecundity for Rhinecanthus verrucosus. Similar results should not be surprising for Scolopsis lineata, which appears to be protogynous. However, the consequence of these patterns in gonochoristic species such as Parupeneus indicus and $R$. verrucosus, particularly with the latter's female-biased overall sex ratio, cannot be overstated.

Despite the value of our results, life-history-based management and conservation requires more than reproductive analysis. As such, aging studies would be a valuable complement to the above results.

\section{ACKNOWLEDGEMENTS}

A private foundation, wishing to remain anonymous, provided financial support. We thank the fishers of Kamiali Wildlife Management Area for collecting specimens (national-level approval included in wildlife export permit \#014214; local-level approval by the Kamiali Wildlife Management Committee). We thank all the residents of Kamiali for their hospitality, openness, and willingness to have their environment and fishing practices examined. Bulisa Iova provided invaluable help obtaining an export permit. This is contribution 2016-003 of the Pacific Biological Survey.

\section{REFERENCES}

Akita Y., Tachihara K. 2014. Age, growth, maturity, and sex changes of monogrammed monocle bream Scolopsis monogramma in the waters around Okinawajima Island, Japan. Fisheries Science 80 (4): 679-685. DOI: $10.1007 / \mathrm{s} 12562-014-0745-7$

Allison G.W., Lubchenco J., Carr M.H. 1998. Marine reserves are necessary but not sufficient for marine conservation. Ecological Applications 8 (Suppl. 1): S79-S92.

DOI: 10.1890/1051-0761(1998)8[S79:MRANBN]2.0.CO;2
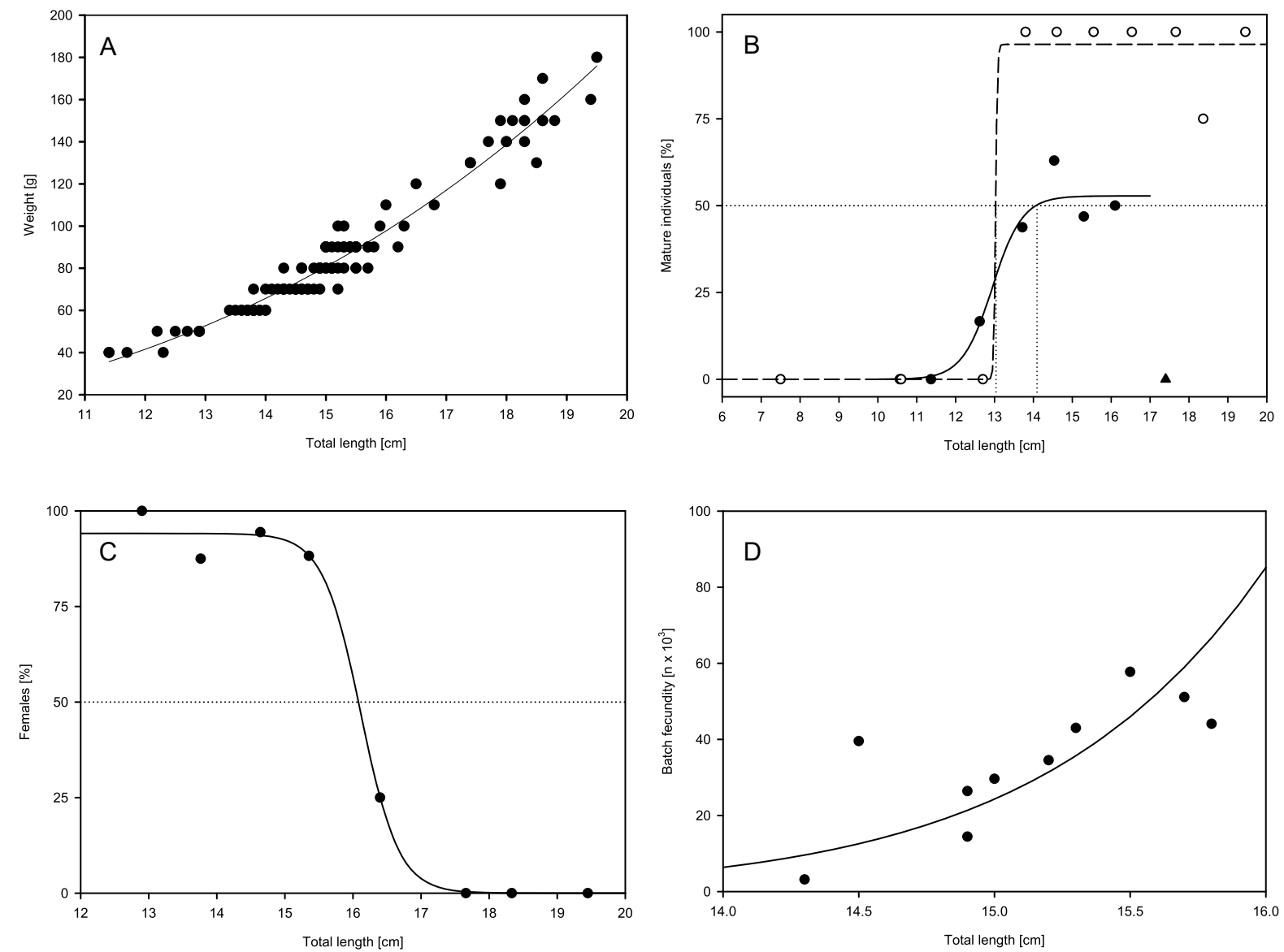

Fig. 4. Rhinecanthus verrucosus from the Kamiali Wildlife Management Area, Papua New Guinea: Length-weight relation (A); $L_{50}$ for males (open circles, dashed line) and females (closed circles, solid line), a single, inactive individual in the largest female size class is represented by a triangle (B); Size-specific sex ratios for mature individuals (C); Lengthfecundity relation $(\mathbf{D})$ 

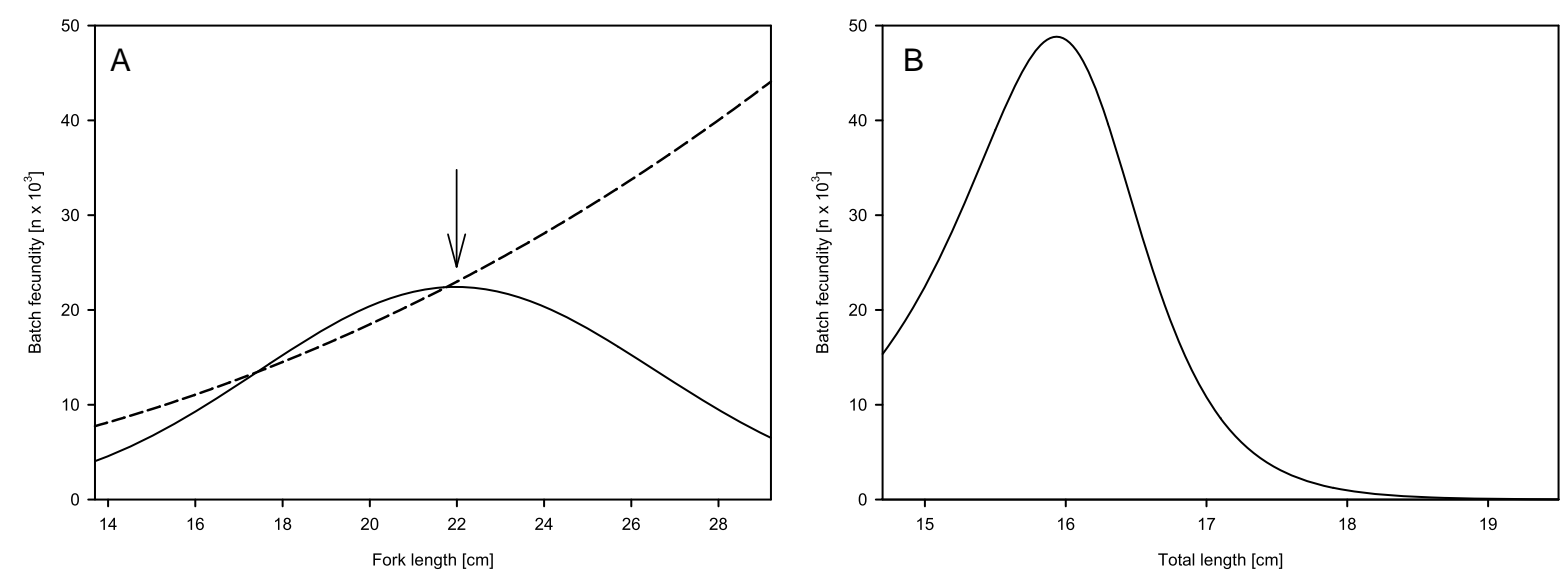

Fig. 5. The influence of size-specific sex ratios on population-level patterns of egg production: the overall $1: 1$ sex-ratio (dashed curve) in Parupeneus indicus appears as expected-The largest individuals are responsible for the majority of egg production, however smaller individuals are responsible for the majority of egg production (arrow) when sizespecific sex ratios are considered (solid curve) (A); Patterns of egg production in Rhinecanthus verrusosus, given observed size-specific sex ratios (B)

Anand P.E.V., Pillai N.G.K. 2002. Reproductive biology of some common coral reef fishes of the Indian EEZ. Journal of the Marine Biological Association of India 44 (1-2): 122-135.

Birkeland C., Dayton P.K. 2005. The importance in fishery management of leaving the big ones. Trends in Ecology and Evolution 20 (7): 356-358.

DOI: $10.1016 /$ j.tree.2005.03.015

Boaden A.E., Kingsford M.J. 2013. Distributions and habitat associations of the bridled monocle bream Scolopis bilineatus (Nemipteridae): A demographic approach. Journal of Fish Biology 83 (3): 618-641.

DOI: $10.1111 /$ jfb. 12200

Ebisawa A. 1990. Reproductive biology of Lethrinus nebulosus (Pisces: Lethrinidae) around the Okinawan waters. Nippon Suisan Gakkaishi 56 (12): 1941-1954. DOI: $10.2331 /$ suisan.56.1941

Froese R. 2004. Keep it simple: Three indicators to deal with overfishing. Fish and Fisheries 5 (1): 86-91. DOI: $10.1111 / j .1467-2979.2004 .00144 . x$

Froese R., Binohlan C. 2000. Empirical relationships to estimate asymptotic length, length at first maturity and length at maximum yield per recruit in fishes, with a simple method to evaluate length frequency data. Journal of Fish Biology 56 (4): 758-773. DOI: $10.1111 /$ j.1095-8649.2000.tb00870.x

Froese R., Tsikliras A.C., Stergiou K.I. 2011. Editorial note on weight-length relations of fishes. Acta Ichthyologica et Piscatoria 41 (4): 261-263.

DOI: 10.3750/AIP2011.41.4.01

Halpern B.S. 2003. The impact of marine reserves: Do reserves work and does reserve size matter? Ecological Applications 13 (Suppl. 1): S117-S137. DOI: 10.1890/1051-0761(2003)013[0117:TIOMRD]2.0.C0;2

Johannes R.E. 1998. The case for data-less marine resource management: Examples from tropical nearshore finfisheries. Trends in Ecology and Evolution 13 (6): 243-246.

DOI: $10.1016 / \mathrm{S} 0169-5347(98) 01384-6$
Lau P.P.F., Sadovy Y. 2001. Gonad structure and sexual pattern in two threadfin breams and possible function of the dorsal accessory duct. Journal of Fish Biology 58 (5): 1438-1453.

DOI: $10.1111 /$ j.1095-8649.2001.tb02298.x

Longenecker K., Langston R. 2008. A rapid, low-cost technique for describing the population structure of reef fishes. Hawaii Biological Survey Contribution 2008-002.

Longenecker K., Langston R., Bolick H. 2013a. Rapid reproductive analysis and length-dependent relationships of Lutjanus biguttatus (Perciformes: Lutjanidae) from Papua New Guinea. Pacific Science 67 (2): 295-301.

DOI: $10.2984 / 67.2 .11$

Longenecker K., Langston R., Bolick H., Kondio U. 2011. Reproduction, catch, and size structure of exploited reef-fishes at Kamiali Wildlife Management Area, Papua New Guinea. Bishop Museum Technical Report No. 57.

Longenecker K., Langston R., Bolick H., Kondio U. 2013b. Rapid reproductive analysis and lengthweight relation of blacktail snapper, Lutjanus fulvus (Actinopterygii: Perciformes: Lutjanidae), from a remote village in Papua New Guinea. Acta Ichthyologica et Piscatoria 43 (1): 51-55.

DOI: 10.3750/AIP2013.43.1.07

Longenecker K., Langston R., Bolick H., Kondio U. 2014. Rapid reproductive analysis and lengthweight relation for red-bellied fusilier, Caesio cuning, and longfin emperor, Lethrinus erythropterus (Actinopterygii: Perciformes: Caesiondiae and Lethrinidae) from a remote village in Papua New Guinea. Acta Ichthyologica et Piscatoria 44 (1): 75-84. DOI: 10.3750/AIP2014.44.1.10

Mant J.C., Moran M.J., Newman S.J., Hesp S.A. Hall N.G., Potter I.P. 2006. Biological characteristics and mortality of western butterfish (Pentapodus vitta), an abundant bycatch species of prawn trawling and 
recreational fishing in a large subtropical embayment. Fishery Bulletin 104 (4): 512-520.

Matsuura K. 2001. Balistidae. Triggerfishes. Pp. 39113928. In: Carpenter K.E., Niem V. (eds.) FAO species identification guide for fishery purposes. The living marine resources of the Western Central Pacific. Vol. 6. Bony fishes part 4 (Labridae to Latimeriidae), estuarine crocodiles, sea turtles, sea snakes and marine mammals. FAO, Rome.

Pavlov D.A., Emel'yanova N.G., Thuan L.T.B., Ha V.T. 2011. Reproduction and initial development of manybar goatfish Parupeneus multifasciatus (Mullidae). Journal of Ichthyology 51 (8): 604-617. DOI: $10.1134 / \mathrm{S} 0032945211050134$

Randall J.E. 2001. Mullidae. Goatfishes (surmullets). Pp. 3175-3200. In: Carpenter K.E., Niem V. (eds.) FAO species identification guide for fishery purposes. The living marine resources of the Western Central Pacific. Vol. 5. Bony fishes part 3 (Menidae to Pomacentridae). FAO, Rome.

Roberts C.M., Polunin N.V.C. 1993. Marine reserves: Simple solutions to managing complex fisheries? Ambio 22 (6): 363-368.
Russell B.C. 1990. FAO species catalogue. Vol. 12. Nemipterid fishes of the world (threadfin breams, whiptail breams, monocle breams, dwarf monocle breams, and coral breams). Family Nemipteridae. An annotated and illustrated catalogue of nemipterid species known to date. FAO Fisheries Synopsis No. 125, FAO, Rome.

Sale P.F., Cowen R.K., Danilowicz B.S., Jones G.P., Kritzer J.P., Lindeman K.C., Planes S., Polunin N.V.C., Russ G.R., Sadovy Y.J., Steneck R.S. 2005. Critical science gaps impede use of no-take fishery reserves. Trends in Ecology and Evolution 20 (2): 74-80.

DOI: $10.1016 /$ j.tree.2004.11.007

Wallace R.A., Selman K. 1981. Cellular and dynamic aspects of oocyte growth in teleosts. American Zoologist 21 (2): 325-343.

DOI: $10.1093 / \mathrm{icb} / 21.2 .325$

Young P.C., Martin R.B. 1985. Sex ratios and hermaphroditism in nemipterid fish from northern Australia. Journal of Fish Biology 26 (3): 273-287. DOI: $10.1111 / \mathrm{j} .1095-8649.1985 . t b 04266 . x$

Received: 1 March 2016 Accepted: 10 September 2016 Published electronically: 30 September 2016 